\title{
Cikkismertetés: Nem segített a HeLP az iskolások elhízásának megelőzésében
}

\author{
Article review: HeLP didn't help to prevent obesity in school children
}

Ismertető: $\quad$ Vitrai József $₫$

Emberi Erőforrások Minisztériuma

Ismertetett cikk: Lloyd J et al. Effectiveness of the Healthy Lifestyles Programme (HeLP) to prevent obesity in UK primary-school children: a cluster randomised controlled trial. Lancet Child Adolesc Health. 2017;2:35-45. doi: 10.1016/S2352-4642(17)30151-7

Beküldve: $\quad$ 2019. 02. 18.

doi: $\quad$ 10.24365/ef.v61i1.563

Kulcsszavak: iskola; egészségfejlesztés; elhízás

Keywords: school; health promotion; obesity

\section{HÁTTÉR}

Bár a gyermekkori túlsúly és elhízás előfordulása az elmúlt három évtizedben jelentősen megnőtt világszerte, kevés bizonyíték áll rendelkezésre a hatékony megelőző beavatkozásokra vonatkozóan. A szerzők célja annak megállapítása, hogy a 9-10 éves gyermekeknél az iskolai alapú, 24 hónapos intervenció képes-e megakadályozni a túlzott súlygyarapodást.

\section{MÓDSZEREK}

Véletlen-kiválasztásos, kontrollált vizsgálatban elemezték az iskolások elhízásának megelőzését célzó Egészséges Életmód Program (Healthy Lifestyles Programme; HeLP) eredményességét. A vizsgálatba 32 délnyugat-angliai iskolát vontak be, amelyeket véletlenszerúen az Egészséges Életmód Programot megvalósító vagy a kontrollcsoportba osztottak. A HeLP négy, egyenként 12 hetes, viselkedésváltozást célzó, az iskolai és a családi környezetre egyaránt kiterjedő aktivitásokat tartalmazó szakaszból állt: az első az 5. évfolyam tavaszán kezdődött, az utolsó a 6. évfolyam őszén. A program dinamikus és interaktív tevékenységeket foglalt magába, mint például testmozgásmúhelyek, oktatás rövid házi feladatokkal, drámafoglalkozások, egyéni célok kitǔzése a viselkedés módosítására (szülői támogatással és a HeLP koordinátorokkal való személyes megbeszélésekkel). A HeLP eredményességét elsődlegesen a mérésen alapuló testtömeg-indexből számolt z-érték kiindulási időpontban és 24 hónap múlva mért értéke közötti különbséggel jellemezték. Ezen túlmenően még elemezték a 18 hónapos z-érték különbségét, a z-érték alapján megállapított túlsúly és az elhízás gyakoriságát, a derékkörfogatot, a testzsírarányt, a mozgásszenzorral követett fizikai aktivitást és a kérdőív alapján felbecsült élelmiszer-fogyasztást.

\section{EREDMÉNYEK}

2012 márciusa és 2013 szeptembere között 32 iskolában 1324 gyermek vett részt a vizsgálatban. 1244 gyermek (628 az intervenciós csoportban és 616 a kontrollcsoportban) rendelkezett TTI adatokkal a vizsgálat indulásakor és a 24 . hónap végén. 
A HeLP-csoportban az átlagos z-érték 0,32 (SD: $1,16)$ volt a kezdési időpontban és $0,35(1,25)$ a 24 . hónapban. A kontrollcsoportban ezek az értékek $0,18(1,14)$ és $0,22(1,22)$ voltak. A csoportok között a kiindulási helyzetben mért különbségek kiszúrése után a z-érték változásának az intervenciós és a kontrollcsoport közötti átlagos különbsége -0,02 $(p=0,57)$ volt.

\section{ÉRTELMEZÉS}

Annak ellenére, hogy elméletileg jól megalapozott, előzetesen gondosan kipróbált, megfelelő minőség- ben végrehajtott beavatkozás történt, a túlsúly vagy az elhízás megelőzésére megvalósított HeLP eredményességét nem lehetett kimutatni. Noha az iskolák ideális helyszínt jelentenek a népességalapú beavatkozások végrehajtására, úgy látszik, hogy az iskolai alapú intervenciók a gyermekek elhízásának visszaszorításához nem elég intenzívek. Az eredmények szerint az ilyen programok nem képesek az iskolai és a családi környezetre elegendő hatást kifejteni. A jövőbeni kutatásoknak még inkább az elhízást befolyásoló társadalmi-gazdasági körülményekre kellene fókuszálniuk, az iskolát komplex rendszerként kezelve.

\section{TANULSÁGOK A HAZAI SZAKEMBEREK SZÁMÁRA}

Ebben a szigorú módszertant alkalmazó vizsgálatban - több másik kutatáshoz hasonlóan - nem sikerült a csupán az iskolai és a családi környezetre irányuló, hagyományosnak tekinthető megközelítésű program eredményességét bizonyítani. ${ }^{1,2}$ A sikertelennek bizonyuló hazai és külföldi beavatkozások megvalósítói figyelmen kívül hagyják, hogy a gyermekek viselkedését sokszereplős, a pedagógusokon és a szülőkön kívül másokat is magába foglaló kapcsolati háló alakítja, sőt az iskolai és családi körülményeken túl az iskola szúkebb és tágabb környezete is meghatározó szerepet játszik. Az elhízás visszaszorításához csakis ennek az összetett rendszernek a feltérképezése, megértése és az így szerzett ismeretekre alapozott beavatkozások vezethetnek. ${ }^{3,4,5,6,7}$

\section{HIVATKOZÁSOK}

\footnotetext{
${ }^{1}$ Erdei G. Cikkismertetés: A hat- és hétéveseket célzó, elhízást megelőző iskolai programok hatékonyságának randomizált, ellenőrzött klasztervizsgálata (WAVES vizsgálat). Egészségfejlesztés folyóirat. 2018,59(6):35-36. 